\title{
Shelf Life Studies of Tomato Powder Incorporated Cold Extrudates
}

\author{
Ronanki Srivalli ${ }^{1}$, B. Anila Kumari ${ }^{1 *}$, K. Uma Maheswari ${ }^{1}$, \\ W. Jessie Suneetha ${ }^{1}$ and B. Neeraja Prabhakar ${ }^{2}$ \\ ${ }^{1}$ Post Graduate and Research Centre, Department of Foods and Nutrition, Professor Jayashankar \\ Telangana State Agricultural University, Rajendranagar, Hyderabad, 500030, India \\ ${ }^{2}$ Department of Horticulture, College of Agriculture, PJTS Agricultural University, \\ Rajendranagar, Hyderabad, 500 030, India \\ *Corresponding author
}

\begin{tabular}{|c|c|}
\hline & A B S T R A C T \\
\hline $\begin{array}{l}\text { Ke y w o r d s } \\
\text { Tomato powder, } \\
\text { Cavatelli extrudates, } \\
\text { lycopene, } \\
\text { TBC, } \\
\text { TMC. }\end{array}$ & $\begin{array}{l}\text { Shelf life studies of food products are gaining impetus due to the consumer awareness } \\
\text { towards quality of the ready to cook products. The present study was designed to assess } \\
\text { the keeping quality and shelf life of tomato powder incorporated rice based cold } \\
\text { extrudates. The Cavatelli extrudates using ingredients: rice flour, wheat flour and tomato } \\
\text { powder in the proportion of } 36: 54: 10 \text { respectively was developed and stored under room } \\
\text { temperature. The stored samples were evaluated for sensory characteristics and microbial } \\
\text { assay at regular intervals for } 60 \text { days. The results showed that the extrudates can be stored }\end{array}$ \\
\hline Article Info & $\begin{array}{l}\text { up to } 45 \text { days at room temperature. The samples showed gradual decrease in lycopene } \\
\text { content during } 0^{\text {th }} \text { to } 60^{\text {th }} \text { day of storage. The microbial load i.e. both TBC and TMC of all }\end{array}$ \\
\hline $\begin{array}{l}\text { Accepted: } \\
15 \text { March } 2017 \\
\text { Available Online: } \\
10 \text { April } 2017\end{array}$ & $\begin{array}{l}\text { the samples was } \leq 2 \mathrm{CFU} / \mathrm{ml} \text { during the storage period of } 60 \text { days. The microbial load was } \\
\text { not observed in all the samples which were stored in LDPE packaging material and stored } \\
\text { under normal room temperature conditions during the initial period of storage as well as up } \\
\text { to } 30 \text { days of storage at } 10^{-1} \text { dilution. }\end{array}$ \\
\hline
\end{tabular}

\section{Introduction}

The requirement for highly nutritious food is escalating because of the commercial opportunity offered by such products, increasing consumer consciousness of the relationship between food and health, and the extensive industrial use for nutrient supplementation, pharmaceutical purposes, food additives and animal feeds (Obradović et $a l ., 2015)$. Tomato is third vegetable next to potato and sweet potato in consumption. Although tomatoes are commonly consumed fresh, over $80 \%$ of tomato consumption comes from processed products such as tomato pulp, puree, paste, sauce, juice, powder and peeled whole tomato (Temitope et al., 2009). Tomato powder is readily marketable due to easy in packaging, transportation, utilization and extended storage life. Tomato powder is widely used in soups, instant sauce premixes, ketchups, sambar, rasam mix, puddings, bakery products, health foods, sweets, biscuits, baby foods, confectionaries, snacks etc (Nagamani, 2014).

Tomato has a limited shelf life at ambient conditions and is highly perishable and is not available in all parts of the country throughout the year at uniform price. These growing market opportunities led to the development 
of technologies for the preservation and sale of the product especially in a dry format. The nutrient content is another important factor that impacts on the consumer choice for preserved products. Processing has tremendous impact on the retention of nutrients and their availability in the body. Processing of tomatoes to a puree or paste enhances bioavailability of lycopene as it will free from tomato matrix. Among the tomato processed products, tomato dried powder is most accessible and convenient form to use in most ready to eat products (Purkayastha and Mahanta, 2011).

The physicochemical characteristics of extruded products depend on the raw ingredients such as rice, wheat and corn. For example, wheat has a high protein and lower starch compared to rice, therefore extruded wheat products are harder and less expanded. It may be possible to improve the physicochemical properties and the lycopene content of the snacks by manipulating the base ingredients (Dehgan-Shoar et al., 2010). Cold forming extruders are operated with moderate conditioning moisture content (30-40\%), low shear and smooth internal barrel surface, deep flight and low screw speed. These are not used for thermoplastic extrusion (Riaz, 2000).

Limited information is available on the addition of tomato derivatives that contain fibre and lycopene, to extruded products. Studies on the possibility of adding tomato powder, to improve the nutritional value of cold extruded products without detracting from their organoleptic properties are scarce. The present study was designed to assess the keeping quality and shelf life of tomato powder incorporated rice based cold extrudates.

\section{Materials and Methods}

Preparation of rice flour: The polished MTU 1001 rice was soaked in water for $4 \mathrm{hrs}$ and drained, sun dried for $1.0 \mathrm{hr}$, milled to fine powder, sieved to particular size of $2 \mathrm{~mm}$ and packed in polythene bag.

\section{Preparation of tomato powder}

Three selected varieties of tomatoes were screened for lycopene content and the variety Pusa Ruby having highest lycopene (Srivalli et al., 2016) content among the three was selected and processed for further making of tomato powder (Nagamani, 2014).

\section{Preparation of cold extrudates}

The Cavatelli extrudates using ingredients: rice flour, wheat flour and tomato powder in the proportion of $36: 54: 10$ respectively were developed by the process of folding and passing through rollers of pasta presto making machine several times. Sheeted dough was extruded through a suitable die (width, 2.0 $\mathrm{mm}$ ), cut to have desired size of extrudates and shade dried for $16 \mathrm{hrs}$. Now these cold extrudates were steamed for $20 \mathrm{~min}$ at $102-$ $105^{\circ} \mathrm{C}$, spread over tray drier and dried for 1 hr at $60^{\circ} \mathrm{C}$.

\section{Shelf life studies}

The extrudate product were stored for 60 days under dry conditions and the product was evaluated for lycopene content, sensory properties and microbial quality on $0^{\text {th }}, 15^{\text {th }}$, $30^{\text {th }}, 45^{\text {th }}$ and $60^{\text {th }}$ day of storage.

\section{Sensory evaluation of stored extrudates}

A semi-trained panel of 15 members using 9 point hedonic scale from PGRC, PJTSAU evaluated the extrudate for colour, texture, flavour, taste and overall acceptability for stored extrudates on $0^{\text {th }}, 15^{\text {th }}, 30^{\text {th }}, 45^{\text {th }}$ and $60^{\text {th }}$ day of storage.

\section{Total bacterial count (TBC)}

The amount of bacteria in a given extrudate sample was determined by using the method 
given by Thambekar et al., (2009). 10 test tubes were sterilized and each one filled with $9.0 \mathrm{ml}$ saline. One gram of sample was thoroughly mixed in $9.0 \mathrm{ml}$ of sterile saline water, from this, $1.0 \mathrm{ml}$ of sample was transferred through a sterile pippet to a screw cap tube containing $9.0 \mathrm{ml}$ saline water, and this gave a dilution of $10^{2}$. Similarly, serial dilutions were made and labeled as $10^{3}, 10^{4}, 10^{5}, \ldots \ldots \ldots 10^{9}$. Simultaneously agar medium was prepared in autoclave at $121{ }^{\circ} \mathrm{C}$ temperature of $15 \mathrm{lb}$ pressure. Sterile petridishes were labelled as $10^{2}, 10^{3} \ldots \ldots 10^{9} .1 .0 \mathrm{ml}$ of the serially dilute of sample was placed in the appropriate labelled sterile petridish to which cooled plate count agar medium was added under sterile environment and mixed thoroughly with the suspension and then allowed to set and then incubated at $37{ }^{\circ} \mathrm{C}$ for 24 hours. Individual colonies were counted and multiplied.

\section{Total mould count (TMC)}

The amount of mould in a given extrudate sample was determined by using the method given by Thambekar et al., (2009). 10 test tubes were sterilized and each one filled with $9.0 \mathrm{ml}$ saline. One gram of sample was thoroughly mixed in $9.0 \mathrm{ml}$ of sterile saline water, from this, $1.0 \mathrm{ml}$ of sample was transferred through a sterile pippet to a screw cap tube containing $9.0 \mathrm{ml}$ saline water, and this gave a dilution of $10^{2}$. Similarly, serial dilutions were made and labeled as $10^{3}, 10^{4}, 10^{5}, \ldots \ldots \ldots 10^{9}$. Simultaneously potato dextrose agar (PDA) medium was prepared in autoclave at $121{ }^{\circ} \mathrm{C}$ temperature of $15 \mathrm{lb}$ pressure.

Sterile petridishes were labelled as $10^{2}, 10^{3} \ldots \ldots 10^{9} .1 .0 \mathrm{ml}$. of the serially dilute of sample was placed in the appropriate labelled sterile petri dish to which cooled plate count agar medium was added under sterile environment and mixed thoroughly with the suspension and then allowed to set and then incubated at $25{ }^{\circ} \mathrm{C}$ for 48 hours. Individual colonies were counted and multiplied.

\section{Statistical analysis}

All the results were statistically analyzed to test the significance of the results using percentages, means, standard deviations and co-relation coefficient (Snedecor and Cochran, 1983).

\section{Results and Discussion}

Shelf life refers to the end of consumer acceptability and is the time at which majority of consumers are displeased with the product. Tomato powder incorporated extrudates were analyzed for its sensory qualities during storage by semi trained panelists using 9.0 hedonic scale for overall acceptability. The details of sensory quality changes, lycopene content and microbial assay during storage were observed at every fifteen days intervals. The responses were analyzed and the mean value of each response variable at every fifteen days of storage is presented in tables 1-3 and figures 1 and 2 .

\section{Sensory evaluation of stored extrudates}

The results of the sensory evaluation of the samples are depicted in table 1 and figure1. On the initial day, the samples recorded high scores for all parameters evaluated i.e. colour, texture, taste, flavor and overall acceptability. However, the profile changed considerably after 30 days of storage. There was a statistically significant decrease $(\mathrm{p}<0.05)$ in the sensory characteristics of extrudates after $60^{\text {th }}$ day of storage. The results showed that the extrudates can be stored up to 45 days at room temperatures. 


\section{Lycopene content in stored extrudates}

The results of lycopene estimation during storage period are presented in Figure 2 . Lycopene content of stored extrudates ranged from 3.72 to $1.71 \mathrm{mg} / 100 \mathrm{~g}$. Statistically significant difference $(\mathrm{P}<0.05)$ was observed in the lycopene content of TP extrudates. The samples showed gradual decrease of lycopene content during $0^{\text {th }}$ to $60^{\text {th }}$ day of storage.

The main causes of tomato lycopene degradation during processing and storage are isomerisation and oxidation. Lycopene content in dehydrated tomato powder was influenced by drying methods, pre-drying treatments and storage condition including packaging material during storage period. During storage the typical red colour of tomato gradually changes to brick-red and then brown. This phenomenon which is known as non-enzymatic browning (NEB) or Millard reaction produces dark pigments and destroys the natural colour of products. The stability of lycopene may be variable in different food systems because of the complex nature of food components the retention of lycopene during storage depends on illumination, temperature, storage time and preblanching treatment.

\section{Microbial quality of stored extrudates}

Microbiological quality is a common criterion used to determine the acceptability and shelf life of dehydrated plant based products. Although some microorganisms are destroyed in the process of drying, this process is not lethal to all microbes. Microbial count of the dehydrated foods depends on handling quality of utensils used during the processing period (Jayathunge et al., 2012).

The formulated TP extrudates were screened for microbial contamination for assessing the shelf life. Microbial quality was done for the control sample and TP extrudate. The samples were tested for total bacterial count (TBC) and total mould count (TMC) during storage at $0^{\text {th }}, 15^{\text {th }}, 30^{\text {th }}, 45^{\text {th }}$ and $60^{\text {th }}$ days. The results are tabulated in tables 2 and 3 .

Table.1 Mean sensory evaluation score of extrudates during storage

\begin{tabular}{|c|c|c|c|c|c|}
\hline $\begin{array}{c}\text { TP } \\
\text { extrudate }\end{array}$ & Colour & Texture & Taste & Flavour & $\begin{array}{c}\text { Overall } \\
\text { acceptability }\end{array}$ \\
\hline $0^{\text {th }}$ day & $7.73^{\mathrm{a}} \pm 0.07$ & $7.40^{\mathrm{b}} \pm 0.91$ & $7.53^{\mathrm{a}} \pm 0.74$ & $6.80^{\mathrm{a}} \pm 0.86$ & $7.26^{\mathrm{a}} \pm 0.88$ \\
\hline $15^{\text {th }}$ day & $7.33^{\mathrm{a}} \pm 0.81$ & $8.00^{\mathrm{a}} \pm 0.65$ & $7.00^{\mathrm{ab}} \pm 0.84$ & $7.46^{\mathrm{a}} \pm 0.91$ & $6.26^{\mathrm{b}} \pm 0.79$ \\
\hline $30^{\text {th }}$ day & $7.00^{\mathrm{ab}} \pm 0.92$ & $7.00^{\mathrm{b}} \pm 0.75$ & $6.66^{\mathrm{bc}} \pm 0.81$ & $6.00^{\mathrm{b}} \pm 0.75$ & $5.66^{\mathrm{b}} \pm 0.90$ \\
\hline $45^{\text {th }}$ day & $6.86^{\mathrm{bc}} \pm 0.64$ & $6.67^{\mathrm{b}} \pm 0.48$ & $6.13^{\mathrm{cd}} \pm 0.91$ & $5.46^{\mathrm{bc}} \pm 1.18$ & $4.73^{\mathrm{c}} \pm 0.12$ \\
\hline $60^{\text {th }}$ day & $6.40^{\mathrm{c}} \pm 0.73$ & $6.27^{\mathrm{b}} \pm 0.59$ & $5.60^{\mathrm{d}} \pm 0.98$ & $5.00^{\mathrm{b}} \pm 0.75$ & $4.46^{\mathrm{c}} \pm 0.64$ \\
\hline Mean & 7.07 & 7.07 & 6.59 & 6.15 & 5.68 \\
\hline CD & 0.5711 & 0.4789 & 0.6105 & 0.6548 & 0.6053 \\
\hline SE & 0.2851 & 0.2391 & 0.3047 & 0.3268 & 0.3022 \\
\hline CV & 11.05 & 9.264 & 12.672 & 14.564 & 14.569 \\
\hline
\end{tabular}

Note: Values are expressed as mean \pm standard deviation of three determinations.

Means within the same column followed by a common letter do not differ significantly at $p \leq 0.05$.

TP - Tomato powder incorporated extrudates 
Table.2 Total bacterial count in extrudates

\begin{tabular}{|c|c|c|c|c|c|c|c|c|c|c|}
\hline \multirow{2}{*}{$\begin{array}{c}\text { No of } \\
\text { dilution }\end{array}$} & $\mathbf{T P}$ & $\mathrm{C}_{1}$ & $\mathbf{T P}$ & $\mathbf{C}_{1}$ & TP & $\overline{\mathbf{C}_{1}}$ & TP & $\mathrm{C}_{1}$ & $\mathbf{T P}$ & $\mathbf{C}_{1}$ \\
\hline & \multicolumn{2}{|c|}{0 days } & \multicolumn{2}{|c|}{15 days } & \multicolumn{2}{|c|}{30 days } & \multicolumn{2}{|l|}{45 days } & \multicolumn{2}{|l|}{60 days } \\
\hline $10^{-1}$ & - & - & - & - & - & - & $2 \mathrm{cfu} / \mathrm{ml}$ & $1 \mathrm{cfu} / \mathrm{ml}$ & $2 \mathrm{cfu} / \mathrm{ml}$ & $1 \mathrm{cfu} / \mathrm{ml}$ \\
\hline $10^{-2}$ & - & - & - & - & - & - & $1 \mathrm{cfu} / \mathrm{ml}$ & - & $1 \mathrm{cfu} / \mathrm{ml}$ & - \\
\hline $10^{-3}$ & - & - & - & - & - & - & - & - & - & - \\
\hline $10^{-4}$ & - & - & - & - & - & - & - & - & - & - \\
\hline $10^{-5}$ & - & - & - & - & - & - & - & - & - & - \\
\hline $10^{-6}$ & - & - & - & - & - & & - & - & - & - \\
\hline $\begin{array}{l}+\mathrm{ve} \\
\text { control }\end{array}$ & \multicolumn{2}{|c|}{-} & \multicolumn{2}{|c|}{-} & \multicolumn{2}{|c|}{-} & \multicolumn{2}{|l|}{-} & \multicolumn{2}{|c|}{$2 \mathrm{cfu} / \mathrm{ml}$} \\
\hline $\begin{array}{l}\text {-ve } \\
\text { control }\end{array}$ & \multicolumn{2}{|c|}{ - } & \multicolumn{2}{|c|}{-} & \multicolumn{2}{|c|}{-} & \multicolumn{2}{|c|}{$1 \mathrm{cfu} / \mathrm{ml}$} & \multicolumn{2}{|c|}{$1 \mathrm{cfu} / \mathrm{ml}$} \\
\hline
\end{tabular}

Note: Values are expressed as mean \pm standard deviation of three determinations.

Means within the same column followed by a common letter do not differ significantly at $p \leq 0.05$. +ve control- Sample without media

-ve control - only media without sample

Table.3 Total mould count in extrudates

\begin{tabular}{|c|c|c|c|c|c|c|c|c|c|c|}
\hline \multirow{2}{*}{$\begin{array}{c}\text { No of } \\
\text { dilution }\end{array}$} & TP & $\overline{C_{1}}$ & TP & $\mathrm{C}_{1}$ & TP & $\mathbf{C}_{1}$ & TP & $\mathbf{C}_{1}$ & $\mathbf{T P}$ & $\mathbf{C}_{1}$ \\
\hline & \multicolumn{2}{|c|}{0 days } & \multicolumn{2}{|c|}{15 days } & \multicolumn{2}{|c|}{30 days } & \multicolumn{2}{|c|}{45 days } & \multicolumn{2}{|l|}{60 days } \\
\hline $10^{-1}$ & - & - & - & - & - & - & $\begin{array}{c}2 \\
\mathrm{cfu} / \mathrm{ml}\end{array}$ & $\begin{array}{c}1 \\
\mathrm{cfu} / \mathrm{ml}\end{array}$ & $2 \mathrm{cfu} / \mathrm{ml}$ & $\begin{array}{c}2 \\
\mathrm{cfu} / \mathrm{ml}\end{array}$ \\
\hline $10^{-2}$ & - & - & - & - & - & - & $\begin{array}{c}1 \\
\mathrm{cfu} / \mathrm{ml}\end{array}$ & $\begin{array}{c}1 \\
\mathrm{cfu} / \mathrm{ml}\end{array}$ & $1 \mathrm{cfu} / \mathrm{ml}$ & $\begin{array}{c}2 \\
\mathrm{cfu} / \mathrm{ml}\end{array}$ \\
\hline $10^{-3}$ & - & - & - & - & - & - & - & - & - & - \\
\hline $10^{-4}$ & - & - & - & - & - & - & - & - & - & - \\
\hline $10^{-5}$ & - & - & - & - & - & - & - & - & - & - \\
\hline $10^{-6}$ & - & - & - & - & - & - & - & - & - & - \\
\hline $\begin{array}{c}\text { +ve } \\
\text { control }\end{array}$ & \multicolumn{2}{|c|}{ - } & \multicolumn{2}{|c|}{ - } & \multicolumn{2}{|c|}{-} & \multicolumn{2}{|c|}{$1 \mathrm{cfu} / \mathrm{ml}$} & \multicolumn{2}{|c|}{$2 \mathrm{cfu} / \mathrm{ml}$} \\
\hline $\begin{array}{c}\text {-ve } \\
\text { control }\end{array}$ & \multicolumn{2}{|c|}{ - } & \multicolumn{2}{|c|}{ - } & \multicolumn{2}{|c|}{ - } & \multicolumn{2}{|c|}{$1 \mathrm{cfu} / \mathrm{ml}$} & \multicolumn{2}{|c|}{$1 \mathrm{cfu} / \mathrm{ml}$} \\
\hline
\end{tabular}

Note: Values are expressed as mean \pm standard deviation of three determinations.

Means within the same column followed by a common letter do not differ significantly at $\mathrm{p} \leq 0.05$.

$+v e$ control- Sample without media

-ve control - only media without sample

TP - Tomato powder incorporated extrudates 
Fig.1 Mean sensory scores of stored extrudates

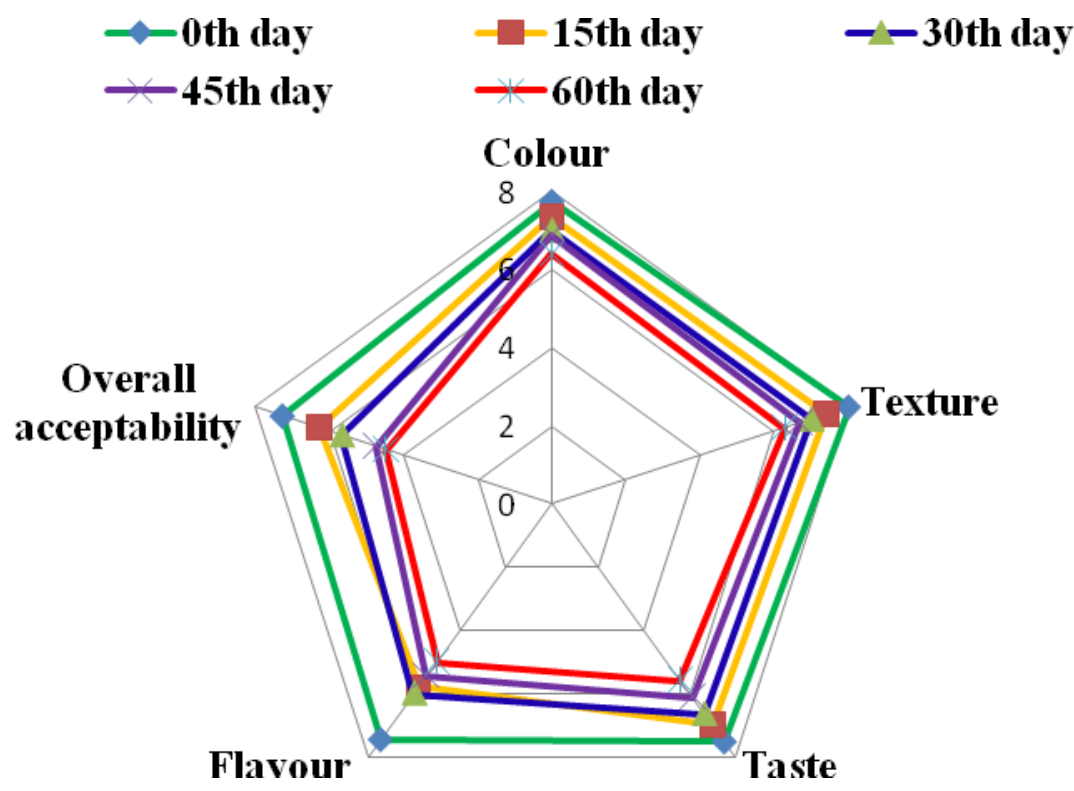

Fig.2 Lycopene content of stored extrudates

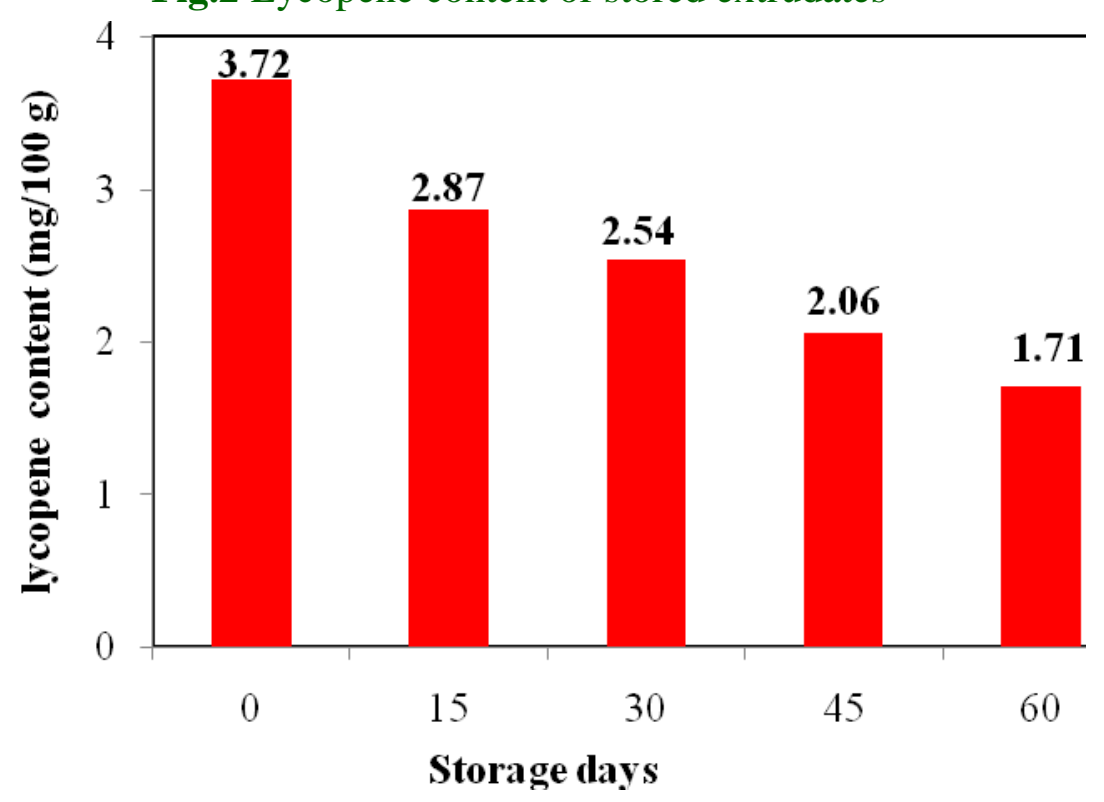

The microbial load i.e. both TBC and TMC of all the samples was $\leq 2 \mathrm{CFU} / \mathrm{ml}$ during the storage period of 60 days. The microbial load was not observed in all the samples which were stored in LDPE packaging material and stored under normal room temperature conditions during the initial period of storage as well as up to 30 days of storage at $10^{-1}$ dilution. This may be because of low moisture content of tomato powder extrudates, avoiding cross contamination and storing in good conditions.

In conclusion, the shelf life studies of tomato powder incorporated extrudates showed significantly changes in lycopene content and 
sensory characteristics. The lycopene tainted more for the samples stored for more than 45 days. A significant difference in microbial load was observed with different storage periods. The TBC and TMC increased with the storage period. Considering the change in lycopene content, overall acceptability and safety, these extrudates may be recommended to store up to 45 days at room temperature. Further, more studies using various advanced techniques of non-thermal processes are needed to extend the shelf life of the extrudates.

\section{References}

Dehgan-Shoar, Z., Hardacre, A.K., Meerdink, G. and Brennan, C.S. 2010. The physico chemical characteristics of extruded snacks enriched with tomato lycopene. Food Chem., 123(4): 1117-1122.

Jayathunge, K.G.L.R., Kapilarathne, R.A.N.S., Thilakarathne, B.M.K.S., Fernando, M.D., Palipane, K.B. and Prasanna, P.H.P. 2012. Development of a methodology for production of dehydrated tomato powder and study the acceptability of the product. J. Agri. Technol., 8(2): 765-773.

Nagamani, G. 2014. Processing technology for tomato powder. J. Scientific Res., 3(2): 210-213.

Obradović, V., Babić,B.J.,. Šubarić, D., Jozinović, A. and Ačkarb, D. PhysicoPhysico-chemical Properties of Corn Extrudates Enriched with Tomato
Powder and Ascorbic Acid. Chem. Biochem. Eng. Q., 29(3): 325-342.

Purkayastha, M.D and Mahanta, C.L. 2011. Physicochemical properties of five different tomato cultivars of Meghalaya and their suitability in food processing. African J. Food Sci., 5: 657667.

Riaz, M.N. 2000. Introduction to extruders and their principles. In extruders in food applications. Pub. Technomic Publishing Co., Inc. Lancaster, PA. 123.

Snedecor, G.W. and Cochran, W.G. 1983. Statistical Methods, Oxford and IBH publishing company, New Delhi.

Srivalli, R., Kumari, A.B., Maheswari, K., Prabhakar, B. and Suneetha, W.J. 2016. Physicochemical Properties of Three Different Tomato Cultivars of Telangana, India and Their Suitability in Food Processing. IRA-Int. J. Appl. Sci., (ISSN 2455-4499), 4(3), 482-489.

Temitope, A.O., Eloho, A.I.P and Olubunmi, I.D. 2009. Lycopene content in tomatoes (Lycopersicon esculentum Mill): Effect of thermal heat and its health benefits.. Global Sci. Books, 3(1): 40-43.

Thambekar, D.H., Murhekar, S.M., Dhanorkar, D.V., Gulhane, P.B. and Dudhane, M.N. 2009. Quality and safety of street vended fruit juices: a case study of Amravati city, India. $J$. Appl. Biosci., 14: 782-787.

\section{How to cite this article:}

Ronanki Srivalli, B. Anila Kumari, K. Uma Maheswari, W. Jessie Suneetha and B. Neeraja Prabhakar. 2017. Shelf Life Studies of Tomato Powder Incorporated Cold Extrudates. Int.J.Curr.Microbiol.App.Sci. 6(4): 1569-1575. doi: https://doi.org/10.20546/ijcmas.2017.604.193 